\title{
LIGHT AND SCANNING ELECTRON MICROSCOPIC STUDIES OF ECHINORHYNCHUS GADI INFECTING THE EUROPEAN EEL ANGUILLA ANGUILLA IN EGYPT
}

\author{
By
}

REWAIDA ABDEL-GABER ${ }^{1,2^{*}}$, and HEWAYDAH E. ABOU SHAFEEY ${ }^{3}$

Department of Zoology, Faculty of Science, Cairo University ${ }^{1}$, Cairo, Egypt

Department of Zoology, College of Science, King Saud University ${ }^{2}$, Riyadh, Saudi Arabia and Department of Zoology, Faculty of Science, Tanta University ${ }^{3}$, Egypt

( ${ }^{\star}$ Correspondence:rewaida@sci.cu.edu.eg)

\section{Abstract}

Fish are important to man as a good source of protein in man's diet and as source of some zoonotic pathogens. This study investigated the helminthes infecting the European eel Anguilla anguilla that collected from Red Sea, Egypt. Only acanthocephala parasite was recovered from the intestine of infected fish with prevalence of $12.5 \%$. The infection was analyzed according to the seasonal prevalence and showed the highest rate during winter rather than the lowest one during summer. Morphological and morphometric analyses for the parasite species revealed that it possess all the characteristic features of the genus Echinorhynchus, but closely related to Echinorhynchus gadi described by Müller (1776). Future molecular studies are recommended for this parasite in order to clarify the actual systematic position.

Keywords: Echinorhynchidae; Echinorhynchus sp.; Morphology

\section{Introduction}

Acanthocephala are a small group of permanent parasites of most vertebrates, including man; with over 1,150 species, belonging to 125 genera and 19 known families (Kennedy, 2006). The relationship between acanthocephala and their hosts were studied previously. Many authors mentioned that the thorn bearing proboscis get much deeper into the intestinal epithelium of fish causing laceration and complete obstruction leading to large mortalities in young fish. This made them easily exposed to secondary damage by other parasites degrading intestinal tissues (Grassi and Calandruccio, 1888; Crompton, 1975; Anderson and May, 1978; Boxrucker, 1979; Uznanski and Nickol, 1982; May, 1985; Glovan and Buron, 1988; Taraschewski, 1989; Moore and Gotelli, 1990; Helluy and Holmes, 1990; Maynard et al., 1996; Dezfuli and Giari, 1999; Dezfuli, 2000; Eissa, 2002; Sparks et al, 2004; Tain et al, 2007).

Echinorhynchus gadi Müller (1776) is an acanthocephalan parasite infecting a wide range of teleost fish hosts in the North Atlantic and North Pacific. It was reported from marine gadid fish, particularly Atlantic cod Gadus morhua L. It infects brackish and fresh water fish (Bauer, 1987). It is the commonest parasite of cod in the southern Baltic Sea (Moller, 1975; Pilecka-Rapacz and Sobecka, 2004). Bykhovskaya-Pavlovskaya et al. (1962) found that species of genus Echinorhynchus caused lesions, ulcerations, inflammation, tumors and connective tissue hypertrophy as the proboscis penetrates intestinal mucosa heavy infection caused high mortality rates.

The present study aimed to provide a full morphological description of the recovered Echinorhynchus parasite infecting the European eel Anguilla Anguilla using light and scanning electron microscopic techniques.

\section{Materials and Methods}

Eighteen specimens of the European eel Anguilla Anguilla (F: Anguillidae) were collected from coasts at the Gulf of Suez of the Red Sea. Fishes were immediately transported to the Parasitology Lab., Department of Zoology Cairo Faculty of Science. Macro- and microscopic examinations of fish were done to detect helminthic infection. Acanthocephalan pa- 
rasites were isolated and relaxed by chilling overnight until particular or complete eversion of the proboscis. Hot formalin acid alcohol was used as fixative. Specimens were washed for several times in distilled water, ethanol dehydrated, stained with Gower's carmine stain, cleared with clove oil and mounted in Canada balsam.

For scanning electron microscopy, specimens were fixed in 3\% buffered glutaraldehyde, post-fixed in osmium tetroxide $\left(\mathrm{OsO}_{4}\right)$ for $2 \mathrm{~h}$, dehydrated in ascending ethanol series, infiltrated with amylacetate, mounted on stubs, coated with gold, examined and photographed by high-resolution Etec Autoscan Jeol 6100 SEM at an accelerating voltage of $20 \mathrm{KV}$.

Normal shaped whole mount parasites were measured by using ocular micrometer calibrated against a stage micrometer slide. Measurements were in millimeter $(\mathrm{mm})$ after Bush et al. (1997), minimum and maximum values were given as mean $( \pm \mathrm{SD})$.

\section{Results}

Ten $(12.5 \%)$ out of 18 specimens of the European eel Anguilla anguilla were found to be naturally infected with Echinorhynchus gadi Müller, 1776. Infection was in intestine. Infection rate increased during winter reached $40 \%(8 / 20)$ and fall to $10 \%(2 / 20)$ in summer.

Morphological description (Figs. 1-7, Tab. 1): Worms, milk-white color, trunk elongated, sub-cylindrical, somewhat swollen anteriorly, a spinose, and covered with transverse striated cuticle. Proboscis was cylindrical, stout, claviform, densely armed with rows of strongly re-curved hooks of various sizes; bigger on proboscis top but progressively smaller backwards. Worms have 18-20 longitudinal rows, with 6-10 hooks per row.

Male body measured 6-10(8 \pm 0.1$) \mathrm{mm} \times 0.3-$ $0.6(0.4 \pm 0.1) \mathrm{mm}$. Proboscis measured 0.23$0.28(0.25 \pm 0.1) \mathrm{mm} \times 0.16-0.20(0.18 \pm 0.1) \mathrm{m}$ $\mathrm{m}$. Proboscis followed by a short neck. Trunk measured 4.5-5.2(4.8 \pm 0.2$) \mathrm{mm} \times 0.36-0.44$ $(0.40 \pm 0.2) \mathrm{mm}$ width. In middle of trunk, two elliptical testes arranged linearly, posterior to testes, cement glands and lemnisci present. Female body larger than male, measured 7-10 $(8 \pm 0.1) \mathrm{mm} \times 0.34-0.54(0.42 \pm 0.1) \mathrm{mm}$. Proboscis measured $0.25-0.29(0.27 \pm 0.1) \mathrm{mm} \mathrm{x}$ $0.17-0.23(0.20 \pm 0.1) \mathrm{mm}$. Proboscis' hooks similar to those of males. Trunk measured 4.9$6.2(5.4 \pm 0.1) \mathrm{mm} \times 0.39-0.49(0.43 \pm 0.1) \mathrm{mm}$. Proboscis receptacle double walled, twice as long as proboscis. Hooks, very sharp terminal with simple and round roots, each worm with a uterine bell. Uterine bell and uterus present in bulbous swelling at body posterior portion. present Echinorhynchus gadi and previous ones.

\begin{tabular}{|c|c|c|c|c|c|c|c|c|}
\hline Species & \multicolumn{2}{|c|}{$\begin{array}{c}\text { Echinorhynchus salmonis } \\
\text { Baylis (1928) }\end{array}$} & \multicolumn{2}{|c|}{$\begin{array}{l}\text { E. lageniformis } \\
\text { Ward (1951) }\end{array}$} & \multicolumn{2}{|c|}{$\begin{array}{c}\text { E. gadi } \\
\text { Müller }(1776)\end{array}$} & \multicolumn{2}{|c|}{$\begin{array}{l}\text { Echinorhynchus gadi } \\
\text { (Present study) }\end{array}$} \\
\hline Parameters & Male & Female & Male & Female & Male & Female & Male & Female \\
\hline Host & \multicolumn{2}{|c|}{ Anguilla anguilla } & \multicolumn{2}{|c|}{ Anguilla anguilla } & \multicolumn{2}{|c|}{ Mullus surmuletus } & \multicolumn{2}{|c|}{ Anguilla anguilla } \\
\hline Body (L) & $\begin{array}{c}2.8-4.5 \\
(3.6 \pm 0.52)\end{array}$ & $\begin{array}{c}2.8-4.5 \\
(3.6 \pm 0.52)\end{array}$ & $1.5-5.0$ & $2.5-6.5$ & $7-9$ & $8-11$ & $\begin{array}{c}6-10 \\
(8 \pm 0.1) \\
\end{array}$ & $\begin{array}{c}7-10 \\
(8 \pm 0.1)\end{array}$ \\
\hline Body (W) & $\begin{array}{c}0.54-0.65 \\
(0.58 \pm 0.04)\end{array}$ & $\begin{array}{c}0.54-0.65 \\
(0.58 \pm 0.04)\end{array}$ & $0.5-0.8$ & -- & $0.3-0.5$ & $0.4-0.6$ & $\begin{array}{c}0.3-0.6 \\
(0.4 \pm 0.1)\end{array}$ & $\begin{array}{l}0.34-0.54 \\
(0.42 \pm 0.1)\end{array}$ \\
\hline No. of rows & \multicolumn{2}{|c|}{18} & \multicolumn{2}{|c|}{18} & 18-19 & 14-18 & \multicolumn{2}{|c|}{$18-20$} \\
\hline No. of hooks & $13-14$ & $13-15$ & \multicolumn{2}{|c|}{$8-10$} & 4 & $6-10$ & \multicolumn{2}{|c|}{$6-10$} \\
\hline Proboscis (L) & \multicolumn{2}{|c|}{0.82} & \multicolumn{2}{|c|}{$0.34-0.44$} & 0.8 & 1.1 & $\begin{array}{l}0.23-0.28 \\
(0.25 \pm 0.1)\end{array}$ & $\begin{array}{l}0.25-0.29 \\
(0.27 \pm 0.1)\end{array}$ \\
\hline Proboscis $(\mathrm{W})$ & -- & -- & $\begin{array}{c}0.22- \\
0.46\end{array}$ & $\begin{array}{c}0.18- \\
0.24\end{array}$ & 0.2 & 0.4 & $\begin{array}{c}0.16-0.20 \\
(0.18 \pm 0.1)\end{array}$ & $\begin{array}{c}0.17-0.23 \\
(0.20 \pm 0.1) \\
\end{array}$ \\
\hline Trunk (L) & -- & -- & -- & -- & $\begin{array}{c}3.4-3.9 \\
(3.5 \pm 0.2) \\
\end{array}$ & -- & $\begin{array}{c}4.5-5.2 \\
(4.8 \pm 0.2) \\
\end{array}$ & $\begin{array}{c}4.9-6.2 \\
(5.4 \pm 0.1) \\
\end{array}$ \\
\hline Trunk (W) & -- & -- & -- & -- & $\begin{array}{c}0.38-0.41 \\
(0.39 \pm 0.2) \\
\end{array}$ & -- & $\begin{array}{c}0.36-0.44 \\
(0.40 \pm 0.2) \\
\end{array}$ & $\begin{array}{l}0.39-0.49 \\
(0.43 \pm 0.1) \\
\end{array}$ \\
\hline
\end{tabular}

\section{Discussion}

Echinorhynchus gadi Müller (1776) is the commonest acanthocephalan parasite infecting marine fish worldwide, and found in more than 60 species (Arai, 1989 and Omar, 1987). In the present study, Echinorhynchus gadi was recorded in the intestine of the European eel Anguilla anguilla, similar records given 
by Ekbaum (1938) who described that Echinorhynchus lageniformis infecting the starry flounders Platichthys stellatus and occasionally it was found along the intestine.

Chubb (1964) studied the ecology of Echinorhynchus clavula in four fish (the grayling Thymallus thymallus, pike Esox Lucius, roach Rutilus rutilus, and eel Anguilla anguilla) and found that the total infection rate was $46.0 \%$, $11.5 \%, 16.1 \%$, \& $27.7 \%$, respectively. These agreed with the present study, which recorded Echinorhynchus gadi infecting European eel with a percentage of $12.5 \%$, and the infection increased during winter season to $40 \%$. Also, these results agreed with Barnes (2019) who found that $E$. lageniformis infection rate rise in late winter and early spring in Platichthys stellatus.

In the present study, morphological features corresponded to genus Echinorhynchus. Characters of body, eggs, and hooks coincided with other authors (Müller, 1776; Yamaguti, 1963; David, 1986; Arai, 1989). Also, the neck showed two small pits, openings of solitary gland cell ducts and two sensory papillae, helping proboscis in the attachment and nourishment as well as a defensive role

\section{Conclusion}

This parasite must be considered as Echinorhynchus gadi a new Egyptian host record.

\section{Acknowledgments}

The authors would like to thank Faculty of Science, Cairo University, Cairo, for allowing all facilities to complete this work.

Conflict of interest: Authors neither have conflict of interest nor received fund

\section{References}

Anderson, RM, May, RM, 1978: Regulation and stability of host-parasite population interactions. I. Regulatory processes. J. Anim. Ecol. 47219-47.

Arai, HP, 1989: Acanthocephala, In Guide to the parasites of fish of Canada. Part III, L. Margolis and Z. Kabata (Eds.). Canadian Special Publ. Fisher. Aquat. Sci. 107:1-90.

Barnes, JR, 2019: The morphology and ecology of Echinorhynchus lageniformis Ekbaum, 1938 Acanthocephala (In Press).
Bauer, ON, 1987: Key to the parasites of freshwater fish of SSSR. Metazoan Parasites. Vol. 3; Leningrad, Soviet Academy of Sciences.

Boxrucker, JC, 1979: Effects of a thermal effluxent on the incidence and abundance of the gill and intestinal metazoan parasites of the black bullhead. Parasitology 78:195-206.

Bush, AO, Lafferty, KD, Lotz, JM, Shostak, W, 1997: Parasitology meets ecology on its own terms: Margolis et al. revisited. J. Parasitol. 83, 4: 575-83.

Chubb, JC, 1964: Occurrence of Echinorhynchus clavula (Dujardin, 1845) Nec Hamann, 1892 (Acanthocephala) in the fish of Llyn Tegid (Bala Lake), Merionethshire. J. Parasitol. 50:52-9.

Crompton, DWT, 1975: Relationships between Acanthocephala and their hosts. In: DH, Jennings and DL, Lee, eds. Symbiosis: Symposia of the Society of Experimental Biology, 29; Cambridge University Press, London, UK.

David, JM, 1986: Aeginina longicornis (Amphipoda: Caprellidea), New Intermediate Host for Echinorhynchus gadi (Acanthocephala: Echinorhynchidae). J. Parasitol. 80, 6:1043-5.

Dezfuli, BS, 2000: Study of cement apparatus, cement production and transportation in adult male Neoechinorhynchus rutile (Acanthocephala, Eoacanthocephala). Parasitol. Res. 86:791-6.

Dezfuli, BS, Giari, L, 1999: Amphipod intermediate host of Polymorphus minutus (Acanthocephala), parasite of water birds, with notes on ultrastructure of host-parasite interface. Folia Parasitol. 46: 117-22.

Eissa, IAM, 2002: Parasitic Fish Diseases in Egypt. $1^{\text {st }}$ ed.; Dar El-Nahdda El-Arabia Publishing.

Grassi, B, Calandruccio, S, 1888: Uber einen Echinorhynchus, welcher ausch im Menschen parasitirt und dessen Zwicshenwirth ein Blaps ist. Centralol. Bakt. U. Parasitenk. 3:521-5.

Helluy, S, Holmes, JC, 1990: Serotonin, octopamine, and the clinging behavior induced by the parasite Polymorphus paradoxus (Acanthocephala) in Gammarus lacustris (Crustacea). Can. J. Zool. 68:1214-20.

Kennedy, CR, 2006: Ecology of the Acanthocephala. Cambridge University Press, Cambridge.

Maynard, BJ, DeMartini, L, Wright, WG, 1996: Gammarus lacustris harboring Polymorphus paradoxus show altered patterns of serotonin-like immunoreactivity. J. Parasitol. 82:663-76. 
Moore, J, Gotelli, NJ, 1990: A phylogenetic perspective on the evolution of altered host behaviors: A critical look at the manipulation hypothesis. In: Parasitism and Host Behavior (ed. Barnard, C.J. and Behnke, J.M.).

Müller, OF, 1776: Zoologiee danicee prodromus seu animalium Danire et Norvegiee indigenarum characteres, nomina et synonyma imprimis popularium Havniee 1776, (Cited by Braun, 1894.).

Omar, MA, 1987: Key to the families and sub-families of Acanthocephala, with erection of a new class (Polyacanthocephala) and a new Oder (Polyacanthorhynchida). J. Parasitol. 73, 6:1216-9.

Pilecka-Rapacz, M, Sobecka, E, 2004: Parasitic fauna of young Baltic cod, Gadus morhua callarias L. in the Gulf of Puck, Poland. Acta Ichthyol. Piscat. 34:235-40.

\section{Tain, L, Perrot-Minnot, MJ, Cézilly, F, 2007:}

Differential influence of Pomphorhynchus laevis (Acanthocephala) on brain serotonergic activity in two congeneric host species. Biol. Let. 3:68-71.

Taraschewski, H, 1989: Host-parasite interface of Paratenuisentis ambiguous (Eoacanthocephala) in naturally infected eel and in laboratory-infected sticklebacks and juvenile carp and rainbow trout. J. Paraistol. 75:911-9.

Uznanski, RL, Nickol, BB, 1982: Site selection, growth, and survival of Leptorhynchoides thecatus (Acanthocephala) during the prepatent period in Lepomis cyanellus. J. Parasitol. 68:686-90.

Yamaguti, S, 1963: Systema Helminthum. IV. Monogenea and Aspidocotylea. Interscience Publishers, New York.

Ward, HL, 1951: The species of Acanthocephala described since 1933. J. Tenn. Acad. Sci. 26:282311.

\section{Explanation of figures}

Figs. 1-4: Echinorhynchus gadi infecting Anguilla anguilla. 1: Female with an anterior retractable proboscis (Pr) followed by neck region (N), trunk (T), and terminated at a uterine ball $(\mathrm{U})$. High magnifications 2: Proboscis (Pr) provided with spines (SP) and followed by neck (N). 3: Spines (SP) of proboscis (Pr). 4: Female Posterior end showed uterine ball (U).

Figs. 5-7: SEM of E. gadi showed high magnifications 5: Anterior end with a retractable proboscis (Pr) with spines (SP) followed by neck region (N). 6: Spines (SP) of proboscis (Pr). 7: A uterine ball (UB).

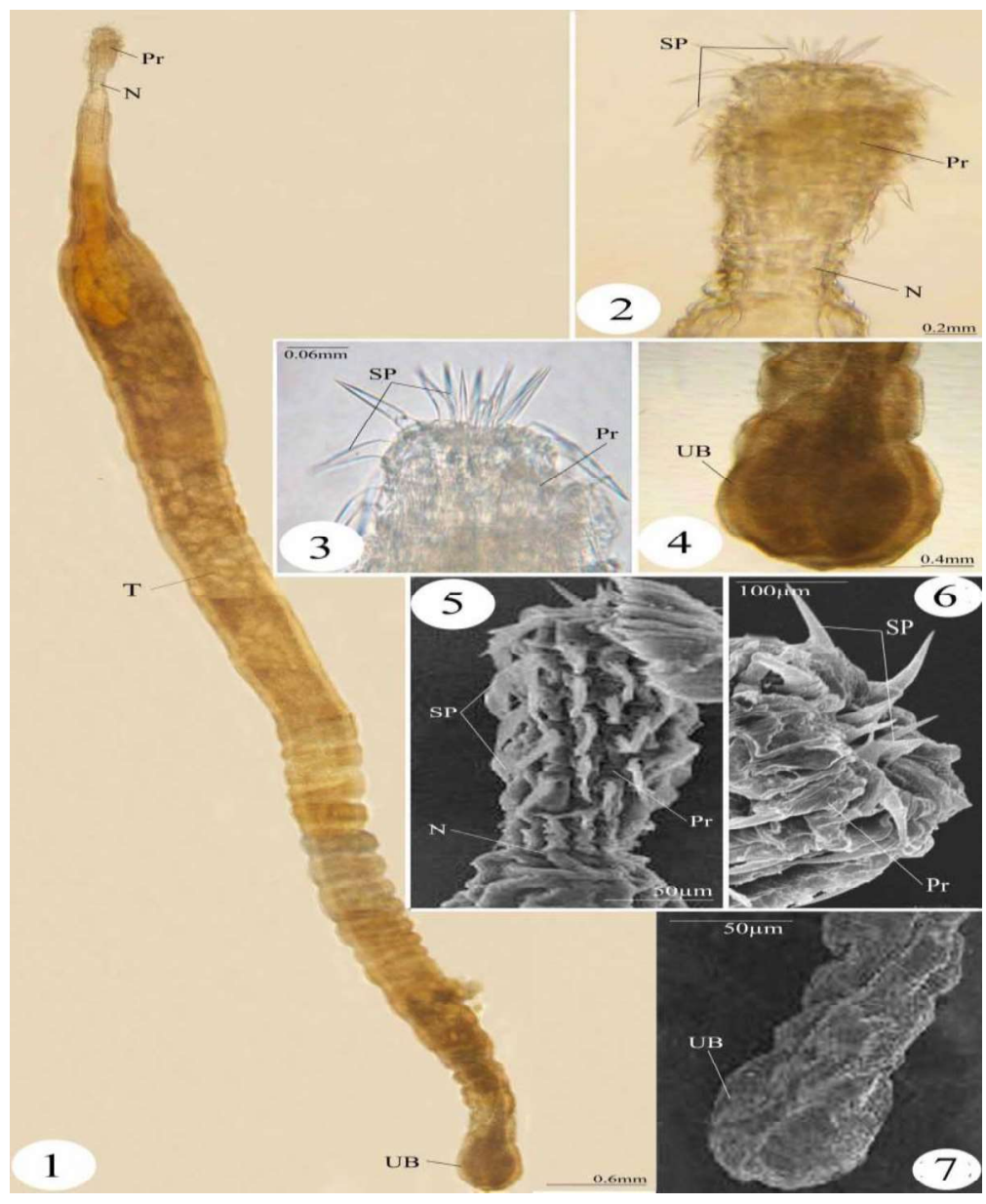


